\author{
IZABELA HASIŃSKA ${ }^{1}$
}

\title{
Z prawnej problematyki nabycia służebności przesyłu przez zasiedzenie
}

\section{Wprowadzenie}

„Haec mea res" - ta rzecz jest moja, ${ }^{2}$ tak rozpoczyna swoje dywagacje na temat prawa własności jej wybitny znawca Profesor Walerian Pańko. Prawo własności to naczelne prawo rzeczowe, daje najpełniejsze władztwo nad rzeczą i jednocześnie nakazuje wszystkim to władztwo respektować. Spór o istotę prawa własności pozostaje otwarty. W kwestii zakresu pojęcia pojęciowego ,rzeczy” nadal aktualna pozostaje tendencja do szerokiego ujmowania tej kategorii. Tak dawniej jak i dziś, znajduje ona uzasadnienie m.in. w potrzebach życia, w rosnącym znaczeniu niektórych form energii, twórczości intelektualnej oraz wiedzy technologicznej. ${ }^{3}$

Inaczej na tle prawa własności prezentują się ograniczone prawa rzeczowe. Polegają one na wykonywaniu niektórych uprawnień na cudzej rzeczy, które to uprawnienia zazwyczaj przysługują właścicielowi. Trafnie zwraca się uwagę w doktrynie, ${ }^{4}$ że stanowią one „obciążenia” prawa własności, a sam ich zakres uzależniony jest od charakteru poszczególnych praw. W zamkniętym katalogu ograniczonych praw rzeczowych ustawodawca umieścił instytucję służebności. Od najdawniejszych czasów znane są one jako ograniczenia prawa własności. Obowiązującym podziałem jest podział na służebności gruntowe oraz osobiste. Służebności osobiste dotyczą osób fizycznych, natomiast gruntowe polegają na możliwości obciążenia nieruchomości na rzecz właściciela innej nieruchomości (nieruchomości władnącej) prawem polegającym na tym, że właściciel nieruchomości obciążonej nie może wykonywać na niej określonych uprawnień bądź zobowiązany jest do znoszenia oznaczonych działan..$^{5} \mathrm{O}$ treści służebności gruntowych decyduje obowiązujący porządek prawny. Mogą one powstać na mocy umowy, orzeczenia sądowego, decyzji administra-

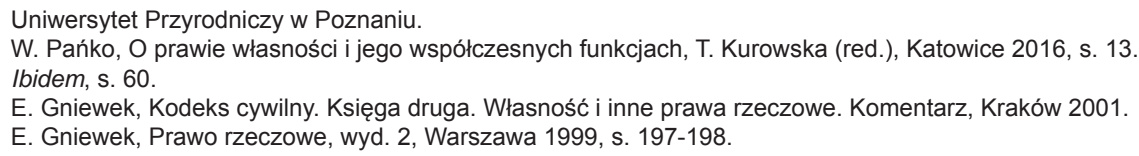


cyjnej oraz w drodze zasiedzenia. Służebności gruntowe będąc prawami rzeczowymi są skuteczne erga omnes.

O służebnościach gruntowych - ponadczasowo - wywodził Profesor Ernest Till, wskazując, że w przeciwieństwie do praw zastawniczych czy emfiteutycznych (użytkowych), ilość postaci służebności gruntowych jest wręcz nieograniczona, jak nieograniczona jest ilość uprawnień właścicielskich, które służebności mogą ograniczać, byleby spełniały generalne wymagania stawiane służebnościom. ${ }^{6}$

\section{Prawo służebności przesyłu}

Prawo służebności przesyłu stanowi szczególną, wyodrębnioną odmianę służebności gruntowej i powoduje ono ograniczenie prawa własności. Ograniczenie to, z uwagi na swój cel, pozostaje w granicach dyspozycji normy konstytucyjnej zawartej w przepisie art. 31 Konstytucji RP. Ma ono służyć bezpieczeństwu energetycznemu państwa, ochronie środowiska oraz zdrowia. ${ }^{7}$ Prawo służebności przesyłu zostało wprowadzone ustawą nowelizującą z dnia 30 maja 2008 r. o zmianie ustawy - Kodeks cywilny oraz niektórych innych ustaw - przepisy art. $305^{1}$ k.c. i następne. ${ }^{8}$ Weszła ona $\mathrm{w}$ życie z dniem 3 sierpnia $2008 \mathrm{r}$. Wprowadzenie prawa służebności przesyłu było odpowiedzią ustawodawcy na postulaty zgłaszane przez przedsiębiorców przesyłowych dotyczące uregulowania kwestii korzystania z nieruchomości, na których pobudowano bądź planuje się pobudować urządzenia przesyłowe. Stosownie do treści art. $305^{1}$ k.c. nieruchomość można obciążyć na rzecz przedsiębiorcy, który zamierza wybudować lub którego własność stanowią urządzenia, o których mowa w art. 49 § 1 k.c., prawem polegającym na tym, że przedsiębiorca może korzystać w oznaczonym zakresie z nieruchomości obciążonej, zgodnie z przeznaczeniem tych urządzeń (służebność przesyłu). Natomiast, zgodnie $\mathrm{z}$ art. $305^{2} \S 1$ i 2 k.c., jeżeli właściciel nieruchomości odmawia zawarcia umowy o ustanowienie służebności przesyłu, a jest ona konieczna dla właściwego korzystania z urządzeń, o których mowa w art. 49 § 1, przedsiębiorca może żądać jej ustanowienia za odpowiednim wynagrodzeniem. W sytuacji, w której przedsiębiorca odmawia zawarcia umowy o ustanowienie służebności przesyłu, a jest ona konieczna do korzystania z urządzeń, o których mowa w art. 49 § 1, właściciel nieruchomości może żądać odpowiedniego wynagrodzenia w zamian za ustanowienie służebności przesyłu. Urządzenia, o których mowa w art. 49 § 1 k.c. to urządzenia służące do doprowadzania lub odprowadzania płynów, pary, gazu, energii elektrycznej oraz inne urządzenia podobne nie należą do części składowych nieruchomości, jeże-

\footnotetext{
6 E. Till, Prawo prywatne austriackie. Wykład prawa rzeczowego austriackiego. Prawo własności, służebności i zastawu, tom. II, Lwów 1892, s. 322-323.

P. Lewandowski, Służebność przesyłu w prawie polskim, Warszawa 2014.

Dz.U. z 2008 r. Nr 116, poz. 731.

Zwane dalej choć nieprecyzyjnie służebnością przesyłu.
} 
li wchodzą w skład przedsiębiorstwa. Celem wprowadzonej regulacji było więc zagwarantowanie przedsiębiorcom przesyłowym dostępu do urządzeń przesyłowych pobudowanych na cudzym gruncie oraz umożliwienie korzystania z cudzej nieruchomości w sytuacji budowy nowych urządzeń przesyłowych. ${ }^{10}$ Stronami stosunku prawnego związanego z ustanowieniem służebności przesyłu jest przedsiębiorca przesyłowy jako uprawniony z tytułu służebności przesyłu, powinien on być także właścicielem urządzeń wymienionych wskazanych w art. 49 § 1 k.c. oraz właściciel nieruchomości obciążonej. Za poglądem prezentowanym $\mathrm{w}$ doktrynie ${ }^{11}$ podmiotem tym może być również Skarb Państwa i jednostka samorządu terytorialnego. Przez nieruchomość obciążoną należy rozumieć nieruchomość, na której posadowiono urządzenia przesyłowe będące własnością przedsiębiorcy przesyłowego bądź nieruchomość, co do której taki przedsiębiorca ma dopiero zamiar je pobudować. Mając na względzie czas, od którego obowiązuje regulacja dotycząca służebności przesyłu wskazać należy, iż w poprzedzającym niniejszą regulację stanie prawnym także możliwe było ustanowienie takowej służebności w ramach odpowiedniego ukształtowania treści służebności gruntowej. W roli uprawnionego do korzystania $\mathrm{z}$ nieruchomości obciążonej występuje przedsiębiorstwo energetyczne, zaś uprawnienia nabywane $\mathrm{w}$ granicach tegoż prawa obejmują budowę i eksploatację urządzeń przesyłowych. ${ }^{12} \mathrm{Na}$ tle podjętego tematu dynamiczne pozostaje orzecznictwo. W postanowieniu z dnia 18 września 2014 r. Sąd Najwyższy wskazał, że „w skład przedsiębiorstwa przesyłowego wchodzą nieruchomości oraz stanowiące jego własność urządzenia przesyłowe naziemne lub podziemne, w zależności od rodzaju przedsiębiorstwa. W wypadku przedsiębiorstwa energetycznego linie energetyczne stanowią składnik przedsiębiorstwa, słupy i linie stanowią bowiem element sieci pozostający z nią w związku funkcjonalnym, niezależnie od tego, czy są posadowione na nieruchomości obciążonej. Zasadnicze znaczenie należy przyznać więc temu trwałemu funkcjonalnemu związkowi sieci przesyłowej ze składnikami przedsiębiorstwa w znaczeniu przedmiotowym oraz celowi ustanowienia służebności odpowiadającej treścią służebności przesyłu, którym jest zwiększenie użyteczności nie konkretnie oznaczonej nieruchomości, a zwiększenie użyteczności przedsiębiorstwa; w tym wypadku chodzi o ułatwienie przesyłania i dystrybucji energii elektrycznej, które odbywa się za pomocą linii napowietrznych połączonych ze stacjami elektroenergetycznymi. $Z$ tych względów, w stanie prawnym obowiązującym przed dniem wejścia w życie art. $305^{1}$ k.c., tj. 3 sierpnia 2008 r., na podstawie art. 285 i 292 k.c., stosowanych przez analogię, możliwe było nabycie przez zasiedzenie służebności

10 E. Gniewek, Nowy rodzaj służebności-służebność przesyłu, „Acta Universitatis Wratislaviensis. Prawo 2009, nr 308, s. 139.

11 G. Matusik, Własność urządzeń przesyłowych a prawa do gruntu, Warszawa 2013, s. 358 oraz M. Tomkiewicz, Służebność przesyłu na gruntach podmiotów konfesyjnych w Polsce, Wybrane zagadnienia, ,,Przegląd Sądowy” 2014, nr 7-8, s. 51.

12 Zob. np. uchwałę Sądu Najwyższego z dnia 7 października 2007 r., sygn. akt III CZP 89/08; postanowienie Sądu Najwyższego z dnia 9 października 2014 r., sygn. akt IV CSK 32/14, niepubl. 
o treści odpowiadającej służebności przesyłu na rzecz przedsiębiorstwa przesyłowego bez potrzeby wskazania i wykazania przez wnioskodawcę danych identyfikujących nieruchomość władnącą". ${ }^{13}$ Natomiast w innym orzeczeniu Sąd Najwyższy ustalił, że „odstąpienie w drodze wykładni od konieczności określenia w orzeczeniu nieruchomości władnącej, na rzecz której nastąpił ex lege skutek zasiedzenia, nastąpiło $\mathrm{w}$ rezultacie odwołania się do pojęcia przedsiębiorstwa $\mathrm{w}$ ujęciu przedmiotowym i przyjęcia domniemania, że składnikiem przedsiębiorstwa przesyłowego jest zawsze taka nieruchomość. Przy tego rodzaju koncepcji brak określenia nieruchomości władnącej jest tylko technicznym uproszczeniem służącym przyspieszeniu postępowania i nie świadczy o braku wystąpienia przesłanki merytorycznej w postaci nieruchomości władnącej”. ${ }^{14}$

Po wprowadzeniu regulacji w zakresie służebności przesyłu to głównie właściciele, na których nieruchomościach pobudowano urządzenia przesyłowe zaczęli masowo zgłaszać wnioski o odpłatne ustanowienie służebności obciążających ich nieruchomości. Z kolei przedsiębiorcy przesyłowi, w toku postępowań sądowych niemalże w każdej sprawie podejmowali obronę zgłaszając zarzut zasiedzenia służebności przesyłu. Sama kwestia możliwości zasiedzenia służebności przesyłu nadal ${ }^{15}$ wywołuje liczne spory zarówno w doktrynie, jak i w praktyce prawniczej. W tym miejscu zaznaczyć należy, choć tylko marginalnie, iż w ramach zarzutu zasiedzenia konieczne jest wykazanie, że przedsiębiorca przesyłowy i jego poprzednicy prawni korzystali z cudzej nieruchomości dokładnie w taki sposób, w jaki korzystałby z niej podmiot, któremu przysługuje służebność przesyłu (od 2008 r.) lub służebność analogiczna (podobna) do służebności przesyłu (do 2008 r.), tj. poprzez korzystanie z trwałych i widocznych urządzeń, w tym wypadku służących do przesyłu energii elektrycznej (przesyłanie energii, dokonywanie ich konserwacji, przeglądów i napraw). W doktrynie przedstawiono wiele poglądów co do dopuszczalności i warunków nabycia służebności przesyłu lub służebności podobnej do służebności przesyłu, ${ }^{16} \mathrm{~W}$ szczególności zaś dominujący obecnie w nauce pogląd niedopuszczający takiej możliwości przed 2018 r. (w okolicznościach dobrej wiary) bądź 2023 rokiem (w okolicznościach złej wiary). Ramy niniejszego artykułu nie pozwalają jednak na szczegółowe omówienie tej złożonej problematyki, stąd artykuł ograniczy się do przedstawienia jedynie ram tego ograniczonego prawa rzeczo-

Postanowienie Sądu Najwyższego z dnia 18 września 2014 r., sygn. akt V CSK 553/13, niepubl.

Postanowienie Sądu Najwyższego z dnia 4 lipca 2014 r., sygn. akt II CSK 551/13, niepubl.

Zob. np. wyrok Sądu Najwyższego z dnia 9 grudnia 2009 r., sygn. akt IV CSK 201/09, niepubl. i stanowiska odmienne np. w postanowieniu Sądu Najwyższego z dnia 4 października 2006 r., sygn. akt II CSK 119/06, niepubl. i z dnia 10 lipca 2008 r., sygn. akt III CSK 73/08, niepubl. oraz uchwałę z dnia 22 października 2009 r., sygn. akt III CZP 70/09, ,,Orzecznictwo Sądu Najwyższego Izba Cywilna” 2010, nr 5, poz. 64.

Np. B. Rakoczy, Zasiedzenie służebności przesyłu, Warszawa 2014; P. Lewandowski, Służebność przesyłu w prawie polskim, Warszawa 2014; M. Balwicka-Szczyrba, Korzystanie z nieruchomości przez przedsiębiorców przesyłowych-właścicieli urządzeń przesyłowych, Warszawa 2015; K. Mularski, Problematyka intertemporalna służebności przesyłu, ,Kwartalnik Prawa Prywatnego” 2015, nr 1, s. 91-152. 
wego, jakim jest prawo służebności przesyłu, a rozważania szczegółowe będą koncentrowały się na instytucji nabycia służebności przesyłu poprzez zasiedzenie.

\section{Zasiedzenie i posiadanie służebności}

Zasiedzenie polega na możliwości nabycia prawa przez nieuprawnionego posiadacza wskutek upływu oznaczonego w ustawie terminu, natomiast długość tego terminu uzależniona jest od dobrej lub złej wiary w chwili nabycia posiadania. Posiadaczem rzeczy jest tak ten podmiot, który faktycznie nią włada jak właściciel (posiadacz samoistny), jak i ten, kto nią faktycznie włada jak użytkownik, zastawnik, najemca, dzierżawca lub mający inne prawo, z którym łączy się określone władztwo nad cudzą rzeczą (posiadacz zależny). ${ }^{17}$ Zaznaczenia wymaga też różnica pomiędzy posiadaniem a dzierżeniem. Polega ona na odróżnieniu elementu woli - dzierżyciel ma wolę władania za kogo innego, natomiast posiadacz samoistny włada w swoim interesie. Zgodnie z treścią art. 172 k.c. posiadacz nieruchomości nie będący jej właścicielem nabywa własność, jeżeli posiada nieruchomości nieprzerwanie od lat dwudziestu jako posiadacz samoistny, chyba że uzyskał posiadanie w złej wierze. Po upływie lat trzydziestu posiadacz nieruchomości nabywa jej własność choćby uzyskał posiadanie w złej wierze. Przy czym wymogiem ustawowym jest ciągłość posiadania samoistnego w oznaczonym okresie. Nie mniej istotne jest także rozpoznanie zdarzenia będącego źródłem nabycia posiadania. Ma ono to znaczenie, że wraz z manifestowanym na zewnątrz zachowaniem posiadacza umożliwia oznaczenie rodzaju posiadania.

Warunki nabycia służebności gruntowej poprzez zasiedzenie zostały zawarte w przepisie art. 292 k.c. W jego treści ustawodawca nakazuje odpowiednio stosować regulacje przewidziane dla zasiedzenia nieruchomości i stanowi, że dla zasiedzenia służebności wymagane jest uprzednie posiadanie tejże służebności przez ustawowo wskazany okres (określony w treści art. 172 k.c.). W zakresie przesłanek decydujących o nabyciu poprzez zasiedzenie służebności przesyłu, to zgodnie z art. $305^{4}$ w zW. z art. 292 k.c. odpowiednie zastosowanie znajdą także przepisy o nabyciu prawa własności nieruchomości w drodze zasiedzenia.

Ze względu na charakter niniejszej służebności, znamiennym jest również fakt, iż posiadanie zmierzające do jej zasiedzenia powinno być postrzegane jako zakresowo odrębne od posiadania zmierzającego do nabycia nieruchomości. ${ }^{18}$ Jednocześnie korzystanie $\mathrm{z}$ nieruchomości obciążonej powinno przebiegać w taki sposób, w jaki korzystałby z niej podmiot, któremu takowa służebność już przysługuje, tj. poprzez pobudowanie trwałych i widocznych urządzeń będących efektem świadomej pra- 
cy człowieka ${ }^{19}$ i służących do przesyłu energii elektrycznej oraz korzystanie z nich. Korzystanie polega m.in. na przesyle energii, przeprowadzeniu ich napraw i konserwacji. ${ }^{20}$ Sąd Najwyższy w orzeczeniu z dnia 26 listopada $1959 \mathrm{r} .^{21}$ wskazał, że pojęcie ,urządzenia” (...) oznacza wynik celowego działania ludzkiego, uzewnętrzniony w trwałej postaci widocznych przedmiotów czy urządzeń, wymagających do ich powstania pracy ludzkiej. Stąd też zwykła polna droga powstała na skutek stałego przejeżdżania pewnym szlakiem i zaznaczona na gruncie jedynie koleinami oraz śladami przepędzania bydła nie jest trwałym i widocznym urząazzeniem, (...) z którego długoletnie korzystanie może doprowadzić do nabycia służebności przejazdu i przechodu przez zasiedzenie. Przy czym stosownie do treści art. $352 \S 1$ k.c. kto faktycznie korzysta z cudzej nieruchomości w zakresie odpowiadającym treści służebności, jest posiadaczem służebności. Zatem warunkiem zasiedzenia służebności przesyłu jest korzystanie przez przedsiębiorcę przesyłowego z trwałego i widocznego urządzenia - art. 292 k.c. np. postawienie na cudzej nieruchomości i korzystanie ze słupa przesyłowego, na którym rozpięto kabel wysokiego, średniego lub niskiego napięcia lub rozpięcie takiego kabla nad gruntem. Mając na uwadze powyższe, brak jest więc przeszkód do uznania przedsiębiorcy, który korzysta z cudzej nieruchomości w zakresie odpowiadającym treści służebności przesyłu, a nie ma tytułu prawnego do władania tą nieruchomością, za posiadacza takiej służebności.

\section{Ciągłość posiadania i upływ czasu}

Obok korzystania przez przedsiębiorcę przesyłowego z trwałego i widocznego urządzenia przesłanką, która decyduje o możliwości nabycia służebności przesyłu poprzez zasiedzenie, jest wskazany ustawowy okres nieprzerwanego posiadania. Został on odmiennie uregulowany dla posiadacza w złej i w dobrej wierze.

Artykuł $50 \S 1$ prawa rzeczowego ${ }^{22}$ stanowił, iż kto posiadał nieruchomość przez lat dwadzieścia, nabywał jej własność, chyba że w chwili objęcia nieruchomości w posiadanie był w złej wierze (zasiedzenie). Natomiast temu, kto posiadał nieruchomość przez lat trzydzieści, nie można zarzucić złej wiary. Marginalnie zaznaczyć też należy, iż w sytuacji kiedy posiadanie zostało uzyskane czynem samowolnym, bieg zasiedzenia rozpoczynał się dopiero z chwilą, gdy dotychczasowy posiadacz utracił roszczenie o przywrócenie utraconego posiadania, co następowało po

Zob. postanowienie Sądu Najwyższego z dnia 17 lutego 1960 r., sygn. akt II CR 951/59, ,,Orzecznictwo Sądu Najwyższego Izby Cywilnej i Karnej” 1961, nr 1, poz. 20; wyrok Sądu Najwyższego z dnia 10 stycznia 1969 r., sygn. akt I CR 516/68, „,Orzecznictwo Sądu Najwyższego Izba Cywilna” 1969, nr 12, poz. 220; postanowienie Sądu Najwyższego z dnia 24 kwietnia 2002 r., sygn. akt V CKN 972/00, ,,Orzecznictwo Sądów Polskich” 2003, z. 7-8, poz. 100.

Por. M. Rafacz-Krzyżanowska, Nabycie służebności gruntowych w drodze zasiedzenia, „,Palestra” 1961, nr 11, s. 33.

21 Zob. wyrok Sądu Najwyższego z dnia 26 listopada 1956 r., sygn. akt I CR 516/59, ,,Orzecznictwo Sądu Najwyższego Izba Cywilna" 1962, nr 1, poz. 8.

Dekret z dnia 11 października 1946 r. - Prawo rzeczowe (Dz.U. z dnia 15 listopada 1946 r.). 
upływie miesiąca od dowiedzenia się o naruszeniu posiadania, nie później jednak niż po upływie 6 miesięcy od dnia naruszenia. ${ }^{23}$

Z dniem 1 stycznia 1965 r. wszedł w życie aktualnie obowiązujący Kodeks cywilny. ${ }^{24} \mathrm{~W}$ pierwotnym brzmieniu art. $172 \S 1$ k.c. przewidywał, iż posiadacz nieruchomości nie będący jej właścicielem nabywa własność, jeżeli posiada nieruchomość nieprzerwanie od lat dziesięciu jako posiadacz samoistny, chyba że uzyskał posiadanie w złej wierze (zasiedzenie). Stosownie do treści art. 172 § 2 k.c. w pierwotnym brzmieniu po upływie lat dwudziestu posiadacz nieruchomości nabywa jej własność, choćby uzyskał posiadanie w złej wierze. W tym samym dniu wszedł też w życie przepis art. 177 k.c. Zgodnie z jego treścią, przepisów o nabyciu własności przez zasiedzenie nie stosuje się, jeżeli nieruchomość jest przedmiotem własności państwowej. Wskazane przepisy, tj. art. 172 k.c. w brzmieniu pierwotnym oraz art. 177 k.c., obowiązywały do dnia 30 września 1990 r. Zatem od dnia 1 stycznia 1965 r. do dnia 30 września 1990 r. wymagane okresy posiadania do stwierdzenia zasiedzenia wynosiły: 10 lat dla okresu posiadania w dobrej wierze i 20 lat dla okresu posiadania w złej wierze. Zastrzec równocześnie należy, iż nie można było nabyć przez zasiedzenie własności państwowej. Zmiana ustawowych okresów posiadania wywołała potrzebę regulacji tzw. okresu przejściowego. Został on uregulowany w art. XLI ustawy Przepisy wprowadzające Kodeks cywilny. Stosownie do treści art. XLI $\S 1$ przywołanej ustawy - do zasiedzenia, którego bieg rozpoczą się przed dniem wejścia w życie Kodeksu cywilnego, stosuje się od tej chwili przepisy tego kodeksu; dotyczy to w szczególności możliwości nabycia prawa przez zasiedzenie. Natomiast zgodnie z art. XLI § 2 ustawy Przepisy wprowadzające Kodeks cywilny, jeżeli termin zasiedzenia według Kodeksu cywilnego jest krótszy niż według przepisów dotychczasowych, bieg zasiedzenia rozpoczyna się z dniem wejścia kodeksu w życie; jeżeli jednak zasiedzenie rozpoczęte przed dniem wejścia w życie Kodeksu cywilnego nastąpiłoby przy uwzględnieniu terminu określonego w przepisach dotychczasowych wcześniej, zasiedzenie następuje z upływem tego wcześniejszego terminu.

Następnie z dniem 1 października 1990 r. weszła w życie nowelizacja ustawy - Kodeks cywilny. Zmieniła ona zawarte w art. 172 k.c. wymagane okresy posiadania prowadzące do nabycia własności nieruchomości przez zasiedzenie, równocześnie uchyliła art. 177 k.c. statuujący zakaz ,,zasiadywania” nieruchomości państwowych. Przepis art. 172 \$ 1 k.c. w brzmieniu obowiązującym od dnia 1 października 1990 r. stanowi, iż posiadacz nieruchomości nie będący jej właścicielem nabywa własność, jeżeli posiada nieruchomość nieprzerwanie od lat dwudziestu jako posia-

23 Zob. art. 451 rozporządzenia Prezydenta Rzeczpospolitej z dnia 29 listopada 1930 r. - Kodeks Postępowania Cywilnego (Dz.U. z 1930 r. Nr 83, poz. 651).

24 Art. I ustawy z dnia 23 kwietnia 1964 r. - Przepisy wprowadzające Kodeks cywilny (Dz.U. z 1964 r. Nr 16, poz. 94 z późn. zm.). 
dacz samoistny, chyba że uzyskał posiadanie w złej wierze (zasiedzenie). Zgodnie zaś $\mathrm{z}$ art. 172 § 2 k.c. w brzmieniu obowiązującym od dnia 1 października 1990 r. po upływie lat trzydziestu posiadacz nieruchomości nabywa jej własność, choćby uzyskał posiadanie w złej wierze.

Nie mniejsze znaczenie ma również forma organizacyjno-prawna poprzedników dzisiejszych przedsiębiorców przesyłowych. Dawniej, poprzednicy prawni dominujących przedsiębiorstw przesyłowych funkcjonowali jako przedsiębiorstwa państwowe. Do 1989 r. obowiązywała wyrażona w art. 128 k.c. - zasada jednolitego funduszu własności państwowej. Aktualnie przedsiębiorca przesyłowy, zgodnie z art. $176 \S 1 \mathrm{w}$ zw. z art. 292 k.c., może zaliczyć do okresu swojego posiadania służebności przesyłu, okres posiadania tej służebności przez Skarb Państwa przed dniem 1 lutego 1989 r. Art. 128 k.c. obowiązujący do dnia 31 stycznia 1989 r. uniemożliwiał państwowym osobom prawnym, sprawującym zarząd mieniem państwowym, nabycie jakichkolwiek praw do tego mienia. ${ }^{25}$ Odnosiło to ten skutek, że w okresie obowiązywania art. 128 k.c. to Skarb Państwa, a nie przedsiębiorstwo państwowe, był posiadaczem urządzeń przesyłowych i cudzej nieruchomości, na której je posadowiono i tylko Skarb Państwa, a nie przedsiębiorstwo państwowe, mógł nabyć przez zasiedzenie służebność gruntową przesyłu. Kwestia terminu - od którego przedsiębiorstwo państwowe korzystające z urządzeń przesyłowych na gruncie Skarbu Państwa mogło rozpocząć posiadanie prowadzące do nabycia służebności przez zasiedzenie „dla siebie”, a nie Skarbu Państwa - podejmowana jest w licznych orzeczeniach. W wyroku z dnia 25 listopada 2014 r. Sąd Apelacyjny w Katowicach ${ }^{26}$ wskazał, że ,uwłaszczenie państwowych osób prawnych, co do składników mienia państwowego znajdujących się w ich zarządzie nastąpiło na podstawie ustawy z dnia 29 września 1990 r. o zmianie ustawy o gospodarce gruntami i wywłaszczenia nieruchomości (Dz.U. z 1990 r. Nr 79, poz. 464 ze zm.) oraz przepisów określających ustrój majątkowy państwowych osób prawnych. Dopóty zatem wspomniane uwłaszczenie nie nastąpiło, państwowe osoby prawne nie miały samodzielnych praw do składników mienia państwowego, którym dotychczas zarządzały, nadal wykonywały w tym zakresie jedynie uprawnienia Skarbu Państwa. Dopiero od dnia wejścia w życie tej ustawy, a to od 5 grudnia 1990 r. mogły wykonywać posiadanie „dla siebie”, czyli we własnym imieniu i na swoją rzecz” . Na kanwie przytoczonego orzeczenia można więc uznać, iż początek posiadania prowadzącego do nabycia służebności przesyłu przez przedsiębiorstwo państwowe korzystające z urządzeń przesyłowych na gruncie Skarbu Państwa - ,dla siebie” - to 5 grudnia 1990 r. Jeżeli jednak grunty, które były pierwotnie własnością Skarbu Państwa, a następnie stały się przedmiotem tzw. komunalizacji mienia państwowego, to wówpubl. 
czas z dniem 27 maja 1990 r. grunt stał się własnością gminy. ${ }^{27}$ Wobec takich gruntów objęcie służebności w posiadanie nastąpiło z dniem 27 maja 1990 r.

\section{Dobra i zła wiara w posiadaniu}

Punktem wyjścia dla oceny dobrej i złej wiary posiadacza samoistnego jest art. 7 k.c. Stosownie do jego treści, jeżeli ustawa uzależnia skutki prawne od dobrej lub złej wiary, domniemywa się istnienie dobrej wiary. Zgodnie z art. 341 k.c. domniemywa się zgodność posiadania ze stanem prawnym. Domniemanie dobrej wiary obowiązuje tak długo, jak nie zostanie obalone dowodem przeciwnym. $\mathrm{O}$ istnieniu dobrej lub złej wiary posiadacza decyduje moment objęcia przedmiotu posiadania w posiadanie, ${ }^{28}$ a późniejsze zmiany świadomości posiadacza nie zmieniają tej oceny i nie stanowią podstawy do zmiany długości terminu zasiedzenia. ${ }^{29} \mathrm{~W}$ wyroku z dnia 29 kwietnia 2009 r. Sąd Najwyższy ${ }^{30}$ wskazał, że ,,przedsiębiorca energetyczny, któremu się nie dowiedzie, że on lub jego poprzednik prawny działał bezprawnie stawiając słupy i nieodpłatnie eksploatując linię energetyczną na gruntach leśnych należących do Skarbu Państwa, w zakresie odpowiadającym treści służebności jest zobowiązany do zapłacenia wynagrodzenia za korzystanie z tych gruntów od chwili dowiedzenia się o wytoczeniu przeciwko niemu powództwa o to wynagrodzenie (art. $224 \S 2$ zd. 1, art. 222 § 2 i art. 352 k.c.)". Dobra wiara w znaczeniu subiektywnym oznacza pewien stan psychiczny polegający na błędnym, ale w określonych okolicznościach usprawiedliwionym, mniemaniu o istnieniu prawa lub stosunku prawnego. Złą wiarę można przypisać tej osobie, która wie bądź z łatwością mogła ustalić prawdziwy stan rzeczy. W wyroku z dnia 3 grudnia 2013 r. Sąd Apelacyjny w Białymstoku ${ }^{31}$ stwierdził, że ,przemawia za posiadaniem w złej wierze sytuacja, w której pomiędzy stronami, bądź ich poprzednikami prawnymi, nigdy nie została zawarta umowa regulująca prawa pozwanej do tej części gruntu, na której posadowione zostały urządzenia energetyczne".

\section{Podsumowanie}

Skutkiem upływu terminu zasiedzenia jest ex lege nabycie przez posiadacza samoistnego prawa własności nieruchomości. Następuje ono wraz z upływem ostatniego dnia wyznaczonego terminu. Tym samym gaśnie prawo dotychczasowego właściciela. W toku postępowań wszczynanych przez właścicieli o odpłatne ustanowienie służebności przesyłu obciążającej ich nieruchomości, zarzut zasiedzenia słu-

27 Zob. art. 5 ust. 1 pkt 1 ustawy z dnia 10 maja 1999 r. - Przepisy wprowadzające ustawę o samorządzie terytorialnym i ustawę o pracownikach samorządowych (Dz.U. z 1990 r. Nr 32, poz. 191 z późn. zm.). Zob. postanowienie Sądu Najwyższego z dnia 3 października 2014 r., sygn. akt V CSK 579/13, niepubl. Zob. postanowienie Sądu Najwyższego z dnia 11 marca 2009 r., sygn. akt I CSK 360/08, niepubl. Wyrok Sądu Najwyższego z dnia 29 kwietnia 2009 r., sygn. akt II CSK 560/08, niepubl. Wyrok Sądu Apelacyjnego w Białymstoku z dnia 3 grudnia 2013 r., sygn. akt I ACa 572/13, niepubl. 
żebności przesyłu jest najczęściej zgłaszanym zarzutem przez przedsiębiorców przesyłowych. Jeżeli poprzez postępowanie dowodowe zostanie wykazane, że władztwo wykonywane zarówno przez przedsiębiorcę, jak i jego poprzedników prawnych odpowiadało zakresowi służebności gruntowej przesyłu lub służebności podobnej do służebności przesyłu i nastąpił wymagany upływ czasu, to wówczas nieskuteczny staje się wniosek zazwyczaj właściciela nieruchomości - o jej odpłatne ustanowienie. 


\section{LEGAL ASPECTS OF THE ACQUISITION OF TRANSMISSION EASEMENT BY ACQUISITIVE PRESCRIPTION}

Keywords: ownership, real property, limited property rights, transmission easement, acquisitive prescription, good faith, transmission entrepreneur.

Ownership is the main property right which gives the fullest control over a thing and, simultaneously, imposes the obligation to respect that control. The situation is totally different in respect of limited property rights. The limited property rights entitle a person to exercise some rights, which are typically given to an owner, on another person's thing. The right of transmission easement constitutes a special, separate type of easement and it limits the ownership. The introduction of that right was a legislator's response to the postulates made by transmission entrepreneurs to regulate the use of the real estate on which distribution equipment has been or is planned to be constructed. The possibility to acquire transmission easement by acquisitive prescription still causes numerous disputes both in the doctrine and among legal practitioners. That claim raised by the entrepreneurs entails the necessity to prove that the transmission entrepreneur and their legal predecessors used another person's real estate in exactly the same way as it would have been used by the person who is entitled to the transmission easement (from 2008) or to an easement analogical (similar) to the transmission easement (until 2008), namely by using permanent and visible facilities which in this case are designed to transmit electrical energy (energy transmission, equipment maintenance, checkups and repairs).

\section{Bibliografia:}

Balwicka-Szczyrba M., Korzystanie z nieruchomości przez przedsiębiorców przesyłowych-właścicieli urządzeń przesyłowych, Warszawa 2015.

Gniewek E., Prawo rzeczowe, wydanie 2, Warszawa 1999.

Gniewek E., Kodeks cywilny. Księga druga. Własność i inne prawa rzeczowe. Komentarz, Kraków 2001.

Gniewek E., Nowy rodzaj służebności-służebność przesyłu, Acta Universitatis Wratislaviensis. Prawo 2009 , nr 308.

Lewandowski P., Służebność przesyłu w prawie polskim, Warszawa 2014.

Matusik G., Własność urządzeń przesyłowych a prawa do gruntu, Warszawa 2013.

Mularski K., Problematyka intertemporalna służebności przesyłu, „Kwartalnik Prawa Prywatnego” 2015, $\mathrm{nr} 1$.

Pańko W., O prawie własności i jego współczesnych funkcjach, T. Kurowska (red.), Katowice 2016. 
Rafacz-Krzyżanowska M., Nabycie służebności gruntowych w drodze zasiedzenia, „Palestra” 1961, nr 11.

Rakoczy B., Zasiedzenie służebności przesyłu, Warszawa 2014.

Sokołowski K. P., Posiadanie samoistne a zasiedzenie nieruchomości, „Państwo i Prawo” 2010, z. 11.

Till E., Prawo prywatne austriackie. Wykład prawa rzeczowego austriackiego. Prawo własności, służebności i zastawu, tom II, Lwów 1892.

Tomkiewicz M., Służebność przesyłu na gruntach podmiotów konfesyjnych w Polsce, Wybrane zagadnienia, ,Przegląd Sądowy” 2014, nr 7-8.

Wąsiewicz A., [w:] J. Ignatowicz (red.), System prawa cywilnego. Prawo własności i inne prawa rzeczowe, t. II, Wrocław 1977. 